\title{
Compressive strength of bioactive sol-gel glass foam scaffolds
}

Gowsihan Poologasundarampillai ${ }^{1,2}$, Colman Lam ${ }^{1}$, Anna-Maria Kourkouta ${ }^{1}$, Peter D. Lee $^{1,2}$, Julian R Jones ${ }^{1 *}$

${ }^{1}$ Department of Materials, Imperial College London, South Kensington Campus, London, SW7 2AZ, UK

${ }^{2}$ School of Materials, University of Manchester, Manchester, M13 9PL, UK

*julian.r.jones@imperial.ac.uk 


\begin{abstract}
Larry Hench's $45 \mathrm{~S} 5$ Bioglass ${ }^{\circledR}$ has been used in more than a million patients as a synthetic bone graft, in the form of a particulate. Bioglass is able to stimulate more bone regeneration than other bioactive ceramics. However, it is not commercially available as a porous scaffold with amorphous glass structure because the 45S5 composition crystallises during sintering. The sol-gel foaming process was developed in Hench's laboratory to overcome this problem. Here, we concisely review the work on scaffold development from Hench's group and report new data that show maximum compressive strengths in excess of $5 \mathrm{MPa}$ can be achieved while maintaining the interconnected pore networks required for vascularised bone ingrowth. This was achieved through optimisation of sintering of the sol-gel foams. Sintering of the sol-gel foams was correlated to the network connectivity and silanol content of the sol-gel foams. Changes in strength after immersion in simulated body fluid were found to be small over the times investigated. Relating the dissolution results to in vivo studies indicates that the scaffolds degrade more rapidly in vivo than in vitro.
\end{abstract}

\title{
Introduction
}

Larry Hench's 45S5 Bioglass ${ }^{\circledR}$ was the first artificial material found to form a bond with bone ${ }^{1,2}$, launching the field of bioactive materials ${ }^{3}$. It has the composition 46.1 mol\% $\mathrm{SiO}_{2}, 24.4 \mathrm{~mol} \% \mathrm{Na}_{2} \mathrm{O}, 26.9 \mathrm{~mol} \% \mathrm{CaO}$ and $2.6 \mathrm{~mol} \% \mathrm{P}_{2} \mathrm{O}_{5}$. In vivo studies showed bioactive glasses bond with bone more rapidly than other bioceramics ${ }^{4}$, such as synthetic hydroxyapatite and apatite/wollastonite glass-ceramic. To find out why Bioglass had this enhanced osteogenic potential, Hench formed a Tissue Engineering and Regenerative Medicine Centre with Professor Dame Julia Polak. Their in vitro 
studies indicated their osteogenic properties are due to their dissolution products stimulating osteoprogenitor cells at the genetic level ${ }^{5-8}$. A common strategy for bone regeneration is the implantation of a synthetic bone graft to act as a temporary template (scaffold) for bone growth ${ }^{9}$. The role of the scaffold is to provide a platform on which bone cells can produce new bone matrix. The scaffold must bond with bone (be bioactive), biodegrade at a controlled rate, provide adequate mechanical support and have an interconnected pore network that allows vascularised bone ingrowth, which is hypothesised to be diameters in excess of $100 \mu \mathrm{m}^{9-11}$. Synthetic hydroxyapatite (HA) is commercially available in porous granules and blocks with pore networks that mimic cancellous bone ${ }^{12}$. The original Bioglass cannot be sintered into large scaffolds while maintaining its amorphous structure because the crystallisation onset temperature is too close to its glass transition temperature $\left(\mathrm{T}_{\mathrm{g}}\right)^{13}$. $\mathrm{T}_{\mathrm{g}}$ must be surpassed to enable viscous flow sintering, but crystallisation reduces control of dissolution and reduces bioactivity of the material ${ }^{13}$. This can be overcome, either by tailoring the glass composition to allow sintering ${ }^{13,14}$, or by using the bottom-up sol-gel approach. Using sol-gel, bioactive glass networks assemble at room temperature ${ }^{15,16}$. As melting is not required, sodium is not needed in sol-gel compositions, so typical compositions are ternary ${ }^{15}$, e.g. $58 \mathrm{~S}\left(60 \mathrm{~mol} \% \mathrm{SiO}_{2}, 36\right.$ $\left.\mathrm{mol} \% \mathrm{CaO}, 4 \mathrm{~mol} \% \mathrm{P}_{2} \mathrm{O}_{5}\right)$ or binary, e.g. $70 \mathrm{~S} 30 \mathrm{C}\left(70 \mathrm{~mol} \% \mathrm{SiO}_{2}, 30 \mathrm{~mol} \% \mathrm{CaO}\right)^{17}$, 18. Sol-gel glasses are inherently nanoporous, the pores form at the interstices between coalesced silica nanoparticles ${ }^{16}$ and their size (6-17 $\mathrm{nm}$ for $70 \mathrm{~S} 30 \mathrm{C}$ and $58 \mathrm{~S}^{19,20}$ ) depends on the precursors used, the glass composition and $\mathrm{pH}^{15,21}$. Sepulveda, Jones and Hench used the sol to gel transition, which is the formation of $\mathrm{Si}-\mathrm{O}-\mathrm{Si}$ - network (polycondensation of $\mathrm{Si}-\mathrm{OH}$ groups), to produce porous scaffolds that mimic the macropore architecture of cancellous bone ${ }^{22-24}$. They introduced a foaming 
step (vigorous agitation of the sol with surfactant) into the conventional sol-gel process $^{22}$. The gelation time was accelerated by adding hydrofluoric acid (HF) so that polycondensation occurred in a few minutes. The many variables in the process and their effect on structure property relationships were investigated ${ }^{23,25-29}$. The process was also up-scaled ${ }^{27}$. By sintering at $800^{\circ} \mathrm{C}$ for $2 \mathrm{~h}$, compressive strengths of $2.26 \mathrm{MPa}$ were achieved with a modal interconnect diameter of $100 \mu \mathrm{m}$ between spherical pores with diameters of $300-600 \mu \mathrm{m}$ at $82 \%$ porosity $^{23}$. This is only just inside the range of compressive strength of the trabecular bone (2-12 MPa). Improved strength is needed. In vitro cell culture of human osteoblasts on the foams showed that the glass stimulated mineralised bone nodule formation without addition of growth factors or hormones ${ }^{30-}$

${ }^{32}$. Osteoclasts also seem to remodel the glass surface in culture ${ }^{33}$. In vivo studies confirmed the foams can regenerate bone defects and the scaffolds degrade over time ${ }^{34}$. The reduction in compressive strength of these scaffolds as a function of dissolution time has not been reported in the literature. Sol-gel foaming was replicated by various $\operatorname{groups}^{35-39}$.

The aim here was to investigate whether the compressive strength of the foams could be improved without losing the interconnected pore network, and how immersion in simulated body fluid affects strength. Previous work found crystallisation of the 70S30C composition onset at $845^{\circ} \mathrm{C}^{23}$. To avoid the risk of crystallisation, sintering temperature could not be increased above $800 \mathrm{C}$ therefore sintering time was investigated.

\section{Materials and Methods}

Scaffolds were produced by sol-gel foaming, with the 70S30C composition (70 mol\% $\mathrm{SiO}_{2}, 30 \mathrm{~mol} \% \mathrm{CaO}$ ) as previously described ${ }^{23,27}$. Sol was prepared by mixing the 
following reagents (in order): deionised water, $2 \mathrm{~N}$ nitric acid, tetraethyl orthosilicate (TEOS), and calcium nitrate tetrahydrate (all Sigma) at a molar ratio of water to TEOS ( $\mathrm{R}$ ratio) of 12:1. $50 \mathrm{ml}$ aliquots of sol were foamed by vigorous agitation (Kenwood electric hand mixer) with $0.5 \mathrm{ml}$ Teepol (Thames Mead Ltd.) and $1.5 \mathrm{ml} 5$ vol\% HF (a gelation catalyst). Teepol contains a low concentration mixture of anionic $(15 \%)$ and nonionic surfactants $(5 \%)$. As the gelation point neared, the foamed sol was poured into cylindrical polymethyl pentene moulds, which were then sealed. The samples were aged $\left(60^{\circ} \mathrm{C}\right)$, dried $\left(130^{\circ} \mathrm{C}\right)$ and thermally stabilised $\left(600^{\circ} \mathrm{C}\right)$ then furnace cooled. Cylindrical foams were produced with a geometrically measured bulk density of $0.21 \pm 0.02 \mathrm{gcm}^{-3}$ and reheated to $600^{\circ} \mathrm{C}\left(10^{\circ} \mathrm{C} \mathrm{min}-1\right)$, held at $600^{\circ} \mathrm{C}$ for 1 $\mathrm{h}$ and then heated (again at $10^{\circ} \mathrm{C} \mathrm{min}^{-1}$ ) to sintering temperature of $750^{\circ} \mathrm{C}, 775^{\circ} \mathrm{C}$ or $800^{\circ} \mathrm{C}$ and held for $2 \mathrm{~h}$ or $4 \mathrm{~h}$ before furnace cooling. They were then cut, using a scalpel, into blocks of $15 \times 5 \times 5 \mathrm{~mm}$ and $5 \mathrm{~mm}$ cubes.

Percentage porosity was calculated using $\%$ porosity $=1-\rho_{\mathrm{r}}$, where $\rho_{\mathrm{r}}$ is the relative density, where $\rho_{\mathrm{r}}=\rho_{\mathrm{f}} / \rho_{\mathrm{s}}$, with $\rho_{\mathrm{f}}$ being the geometrical foam density and $\rho_{\mathrm{s}}$ the skeletal density $^{40}$, determined from helium pycnometry (Quantachrome). X-ray diffraction (XRD) patterns were obtained on crushed foams using a Philips PW 1700 series automated XRD spectrometer, using a step scanning method with Cuk $\alpha$ radiation, at 40 $\mathrm{kV}$ and $40 \mathrm{~mA}$, with a $0.040^{\circ} 2 \theta$ step and a count rate of $30 \mathrm{~s}$ per step, from $2 \theta$ values of $10^{\circ}$ to $50^{\circ}$. A LEO 1525 scanning electron microscope (SEM) equipped with a GEMINI field emission column was used to image the foamed scaffolds. Fragments of foamed scaffolds were mounted on sticky carbon tape and sputter coated with chromium to a maximum thickness of $15 \mathrm{~nm}$ before imaging. Images were collected on the in-lens secondary electron detector with an operating voltage of $5 \mathrm{kV}$ and a working 
distance of 5-8 $\mathrm{mm}$. The interconnected pore size distributions were obtained by mercury intrusion porosimetry (Quantachrome PoreMaster 33).

Compression tests were carried out on foams 15 (h) x 5 x 5 mm using a Zwick with a parallel plate crosshead velocity of $0.5 \mathrm{~mm} \mathrm{~min}^{-1}$ and a $500 \mathrm{~N}$ load cell. Five samples were used for each condition. Microcomputed tomography ( $\mu \mathrm{CT}$ ) was performed on a bioactive glass foam 4 (h) $\times 7 \times 7 \mathrm{~mm}$ sintered at $800^{\circ} \mathrm{C}$ for $2 \mathrm{~h}$ after it had just fractured under compression loading. Scans were performed using a commercial $\mu \mathrm{CT}$ unit (Phoenix X-ray Systems and Services $\mathrm{GmbH}$ ) at $8 \mu \mathrm{m}$ voxel resolution.

Foam cubes ( $5 \mathrm{~mm}$ dimensions) were immersed in $50 \mathrm{ml}$ of $(\mathrm{SBF})^{41}$ at $37^{\circ} \mathrm{C}$ and 175 $\mathrm{rpm}$ for $1,4,8,24$ and $168 \mathrm{~h}$ according to an agreed protocol for bioactive glass testing ${ }^{42}$. Since that the cube sized samples were not cut into constant shapes, the amount of the SBF needed was calculated to maintain a consistent mass to SBF volume ratio of $1.5 \mathrm{mg} \mathrm{ml}^{-1}$ 42. Filtered $\mathrm{SBF}$ (using $1 \mu \mathrm{m}$ retention filter paper) was analysed by inductive coupled plasma spectroscopy (ICP, ARL instruments). The instrument detection limits for $\mathrm{Si}, \mathrm{Ca}$ and $\mathrm{P}$ were $0.05,0.10$ and $0.20 \mu \mathrm{g} \mathrm{ml}^{-1}$ respectively. The scaffolds were dried in acetone and analysed by Fourier transform infrared spectroscopy (FTIR) to monitor the growth of the HCA layer. For collection of FTIR spectra, scaffolds were ground in $\mathrm{KBr}$ with a glass to $\mathrm{KBr}$ dilution ratio of 1:100. Spectra were collected using a Mattson Genesis II spectrometer, with a Pike Technologies EasiDiff diffuse reflectance accessory.

\section{Results and Discussion}

Figure 1a is a photograph of foam scaffolds post stabilisation, where the foam was dried and heated to $600^{\circ} \mathrm{C}$ (left) and a similar scaffold following the same thermal 
stabilisation at $600^{\circ} \mathrm{C}$ and then further sintering at $800^{\circ} \mathrm{C}$ for $2 \mathrm{~h}$. As $800^{\circ} \mathrm{C}$ was above $\mathrm{T}_{\mathrm{g}}$ for the 70S30C glass composition $\left(\mathrm{T}_{\mathrm{G} \text { ONSET }}=717^{\circ} \mathrm{C}^{23}\right)$, shrinkage of the scaffold was observed due to viscous flow and further $\mathrm{Si}-\mathrm{O}-\mathrm{Si}$ bond formation through condensation. Pores that were visible to the naked eye were no longer visible after sintering. Figure $1 \mathrm{~b}$ shows a fracture surface of a stabilised scaffold imaged under SEM. Interconnects between pores are visible (black holes). Other interconnects were present, but are out of the plane of the image. Figure 1c shows that the pores were highly interconnected in 3D (voxel size was $8 \mu \mathrm{m}$ ). In order to determine whether the pore networks are suitable for bone regeneration, interconnects must be in excess of $100 \mu \mathrm{m}$, to allow vascularised bone ingrowth ${ }^{10}$.

Figure 2 shows interconnect and pore size distributions for bioactive sol-gel foam scaffolds, stabilised at $600^{\circ} \mathrm{C}$ with initial $\rho_{\mathrm{f}}$ (foam density) of $0.22 \pm 0.02 \mathrm{~g} \mathrm{~cm}^{-3}$ and porosity of $92 \%$, then sintered to $800^{\circ} \mathrm{C}$ to give a $\rho_{\mathrm{f}}$ (foam density) of $0.41 \pm 0.02 \mathrm{~g} \mathrm{~cm}^{-}$ ${ }^{3}$ and porosity of $85 \%$. Modal sizes were excess of $100 \mu \mathrm{m}$ after stabilisation and sintering. After stabilisation at $600^{\circ} \mathrm{C}$, the modal interconnect size was $153 \mu \mathrm{m}$ by mercury porosimetry, decreasing $97 \mu \mathrm{m}$ after sintering ${ }^{24}$. Modal pore diameters from X-ray microtomography $(\mu \mathrm{CT})$ were $743 \mu \mathrm{m}$ after stabilization, decreasing to $561 \mu \mathrm{m}$ after sintering ${ }^{24}$. While the interconnect size is most important for tissue ingrowth, percentage porosity has the largest effect on compressive strength ${ }^{40}$.

In this study, after thermal stabilisation at $600^{\circ} \mathrm{C}$, the foam density was $0.21 \pm 0.02 \mathrm{~g}$ $\mathrm{cm}^{-3}$, with a percentage porosity of $93 \%$. Note the percentage porosity was high due to the presence of strut nanoporosity that is inherent to the sol-gel process ${ }^{23}$. Figure 3 shows the interconnect diameter distributions for each condition tested. XRD patterns 
showed amorphous halos for all conditions (data not shown), which was expected as sintering was below the $\mathrm{T}_{\mathrm{c}}$ ONSET for the composition.

Figure 4 shows a 3D reconstruction of a foam scaffold immediately after fracture (Figure 4a) and Figure 4(b) is a cross-section through (a) showing several fractured pieces of the foam, segmented to different colours, always fracturing in the plane parallel to the load. The stress-strain curves that were obtained from the scaffolds were typical of brittle open cell foams ${ }^{23,40}$, with an elastic compression region, a point of fracture (maximum compressive strength) and then a region where there were continual fracture of pore layers and crushing/collapse of the pores. However the principle crack propagation was not in the direction predicted by Gibson and Ashby. They suggested cellular solids should fail through a crack propagating perpendicular to the load axis, due to sequential buckling/fracture of struts. Here, Figure $4 \mathrm{a}$ and Figure $4 \mathrm{~b}$ show the cracks propagate along the loading axis, splitting the foam into several pieces. This could be due to the spherical nature of the pores and circular morphology of the interconnects, or, perhaps more likely, due to local stress concentrations causing crack initiation at the top of the scaffold in contact with the moving compression platen, then propagating catastrophically down the scaffold.

Table 1 shows the structural and mechanical characterisation results and time to HCA formation in SBF for the scaffolds in this study. Sintering at $750{ }^{\circ} \mathrm{C}$ for $4 \mathrm{~h}$ did not increase the foam density of the scaffolds. The modal interconnect diameter was 104 $\mu \mathrm{m}$ and compressive strength was $2.3 \mathrm{MPa}$, which was similar to the maximum strength obtained in previous studies, where scaffolds sintered for $2 \mathrm{~h}$ at $800^{\circ} \mathrm{C}^{23}$. Sintering for $2 \mathrm{~h}$ at $800^{\circ} \mathrm{C}$, in this study, increased the foam density to $0.45 \pm 0.02 \mathrm{~g} \mathrm{~cm}^{-3}$, but the modal interconnect diameter was larger, at $116 \mu \mathrm{m}$. The increase in density was due to 
the increase in bridging oxygen bonds, decrease in non-bridging bonds (reduction in $\mathrm{Si}-\mathrm{OH}$ groups) due to the polycondensation process and viscous flow. Previous data support this, with nitrogen sorption data showing modal nanopore diameter to decrease from $17 \mathrm{~nm}$ to $12 \mathrm{~nm}^{23}$ and calculations from solid state proton MAS NMR studies indicating that the ratio of $\mathrm{Si}: \mathrm{OH}$ in the glass increased from 2.0 to $8.7^{43}$ as sintering temperature increased from $600^{\circ} \mathrm{C}$ to $800^{\circ} \mathrm{C}$ ( $2 \mathrm{~h}$ dwells $)$.

Compressive strength, of scaffolds sintered at $800^{\circ} \mathrm{C}$ for $2 \mathrm{~h}$, was higher than previously reported even though the modal interconnected pore diameter and percentage porosity were higher. Modal interconnected pore diameter was previously $98 \mu \mathrm{m}$, compared to $116 \mu \mathrm{m}$, and percentage porosity was $82 \%$, compared to $84 \%$ here. Previous studies used foams that were $27 \mathrm{~mm}$ in diameter and $9 \mathrm{~mm}$ in height. Here samples were taller than they were wide $(15 \mathrm{~mm}(\mathrm{~h}) \times 5 \times 5 \mathrm{~mm})$. The higher compressive strength measured in this study could be due to the difference in the sample sizes used. In the previous study samples with volume $>5000 \mathrm{~mm} 3$ were used while in this study it was $\sim 375 \mathrm{~mm} 3$, this is more than 13 times less, which means there would be much lower number of flaws inherent to the material within the smaller samples used in this study when compared to the previous study.

Sintering for $4 \mathrm{~h}$ at $800^{\circ} \mathrm{C}$ reduced the interconnect size from $116 \mu \mathrm{m}$ to $31 \mu \mathrm{m}$, but the compressive strength remained similar. There was therefore no benefit to sinter for longer for bone regeneration applications as the interconnect size became too small. Sintering for longer time seemed to cause reduction in interconnect size in general because sintering at $775^{\circ} \mathrm{C}$ for $4 \mathrm{~h}$ produced a smaller interconnect diameter than sintering at $800^{\circ} \mathrm{C}$ for $2 \mathrm{~h}$. The extra time holding above $\mathrm{T}_{\mathrm{g}}$ seems to cause excess viscous flow. Sintering should therefore not exceed $2 \mathrm{~h}$ for sol-gel foams. 


\section{Apatite formation in SBF}

Apatite formation in SBF is an approximate indication of whether the scaffolds will form HCA in vivo ${ }^{44,45}$. FTIR spectra can contain P-O bending bands at $\sim 571$ and 602 $\mathrm{cm}^{-1}$ that represent crystalline orthophosphate, which, for bioactive glasses in SBF, is likely to be HCA. In FTIR spectra of scaffolds that were immersed in SBF for 1 to 8 $\mathrm{h}$, dual P-O bending bands were not present on any scaffolds, indicating there was no HCA layer present. However, after $4 \mathrm{~h}$, a broad band was observed in spectra taken from all scaffolds, between 620 and $550 \mathrm{~cm}^{-1}$, which is often considered to signify amorphous calcium phosphate deposition (data not shown). Figure 5 shows FTIR spectra for the sol-gel foam scaffolds following immersion in SBF for $24 \mathrm{~h}$ (Figure 5a) and 1 week (Figure 5b). After 24 h, P-O bending bands were found at wavenumbers 563 and $605 \mathrm{~cm}^{-1}$ in spectra from scaffolds sintered at $750^{\circ} \mathrm{C}$ and 775 ${ }^{\circ} \mathrm{C}$ for $4 \mathrm{~h}$. After 1 week, P-O bending bands were present in spectra from all samples.

\section{Compressive strength after immersion in SBF}

Compressive strength was measured after scaffolds were immersed in SBF. The sintering protocol of $800^{\circ} \mathrm{C}$ for $2 \mathrm{~h}$ was used for the scaffolds. Samples used in this study had a slightly higher foam density $\left(0.6 \mathrm{~g} \mathrm{~cm}^{-3}\right.$ compared to the $\left.0.45 \mathrm{~g} \mathrm{~cm}^{-3}\right)$ used in the earlier data. This meant the scaffolds had lower percentage porosity (78\% compared to 84\%) and higher compressive strength (6.0 MPa compared to 4.6 $\mathrm{MPa}$ ). After $2 \mathrm{~h}$ immersion in SBF, the foam density and percentage porosity changed little and while the mean compressive strength decreased to $5.3 \mathrm{MPa}$, the change was within the uncertainty of the experiment. Little change was observed up until $72 \mathrm{~h}$ immersion in SBF. However after 1 week, which was the time at which HCA formation was observed, porosity increased to $86 \%$ and compressive strength decreased to $2.1 \mathrm{MPa}$. This is still within the compressive strength of 
cancellous bone. This implies that once dissolution has occurred to the point of HCA formation, porosity increases and mechanical strength begins to decrease. This would imply bone ingrowth should begin before 1 week in vivo, to prevent the risk of fracture. In vivo studies on 70S30C foam scaffolds showed excellent vascularized bone ingrowth after 11 weeks $^{34}$, in a rat tibia model, but only when the foams were preconditioned in culture media for 3 days in vitro. This was attributed to the scaffolds that were not preconditioned releasing a burst of $\mathrm{Ca}^{2+}$ that remained trapped inside the pores, causing a local $\mathrm{pH}$ increase inside the pores.

Figure 6a shows FTIR spectra of the scaffolds used in the SBF study. It shows that HCA formation started at $24 \mathrm{~h}$ and 3 days immersion in SBF. SEM images show that a precipitate formed on the the surface of the scaffolds after 3 days (Figure 6b) and matured into typical HCA-like morphology after 7 days (Figure 6c).

\section{Conclusions}

Bioactive sol-gel foams developed in Hench's laboratory were the first amorphous bioactive glass scaffolds with interconnected pore networks that mimic the morphology of cancellous bone with interconnects suitable for vascularised bone ingrowth. The 70S30C composition with modal interconnect diameters of $116 \mu \mathrm{m}$ can be made to have a compressive strength of 4.6 MPa. Immersion in SBF for three days has little effect on mechanical properties or percentage porosity but after 1 week, compressive strength can be decreased to less than half of the dry value.

\section{Acknowledgements}


The authors acknowledge the Royal Academy of Engineering/EPSRC postdoctoral

Fellowship, The Philip Leverhulme Prize for Engineering and EPSRC grant EP/E057098/1. 3-D imaging was in part carried out at the Manchester X-ray Imaging Facility and the Research Complex at Harwell, funded in part by the EPSRC grant $\mathrm{EP} / \mathrm{I} 02249 \mathrm{X} / 1$.

\section{References}

1. L. L. Hench, R. J. Splinter, W. C. Allen, T. K. Greenlee. Bonding mechanisms at the interface of ceramic prosthetic materials, Journal of Biomedical Materials Research Biomedical Materials Symposium 2(1) 117-141 (1971).

2. L. L. Hench, H. A. Paschall. Direct chemical bonding of bioactive glassceramic materials and bone, J Biomed Mater Res Symp 4 25-42 (1973).

3. L. L. Hench. Opening paper 2015- Some comments on Bioglass: Four Eras of Discovery and Development, Biomedical Glasses 1(1) 1-11 (2015).

4. H. Oonishi, L. L. Hench, J. Wilson, F. Sugihara, E. Tsuji et al. Quantitative comparison of bone growth behavior in granules of Bioglass (R), A-W glassceramic, and hydroxyapatite, Journal of Biomedical Materials Research 51(1) 3746 (2000).

5. I. D. Xynos, A. J. Edgar, L. D. K. Buttery, L. L. Hench, J. M. Polak. Geneexpression profiling of human osteoblasts following treatment with the ionic products of Bioglass (R) 45S5 dissolution, Journal of Biomedical Materials Research 55(2) 151-157 (2001).

6. L. L. Hench, J. M. Polak. Third-generation biomedical materials, Science 295(5557) 1014-1017 (2002).

7. I. D. Xynos, A. J. Edgar, L. D. K. Buttery, L. L. Hench, J. M. Polak. Ionic products of bioactive glass dissolution increase proliferation of human osteoblasts and induce insulin-like growth factor II mRNA expression and protein synthesis, Biochemical and Biophysical Research Communications 276(2) 461-465 (2000).

8. I. D. Xynos, M. V. J. Hukkanen, J. J. Batten, L. D. Buttery, L. L. Hench et al. Bioglass 45S5 stimulates osteoblast turnover and enhances bone formation in vitro: Implications and applications for bone tissue engineering, Calcified Tissue International 67(4) 321-329 (2000).

9. J. R. Jones. Review of bioactive glass: From Hench to hybrids, Acta Biomaterialia 9(1) 4457-4486 (2013).

10. S. F. Hulbert, S. J. Morrison, J. J. Klawitte. Tissue Reaction to Three Ceramics of Porous and Non-Porous Structures, Journal of Biomedical Materials Research 6(5) 347-374 (1972).

11. C. E. Holy, M. S. Shoichet, J. E. Davies. Engineering three-dimensional bone tissue in vitro using biodegradable scaffolds: Investigating initial cell-seeding density and culture period, Journal of Biomedical Materials Research 51(3) 376382 (2000).

12. R. Z. LeGeros. Properties of osteoconductive biomaterials: Calcium phosphates, Clinical Orthopaedics and Related Research (395) 81-98 (2002). 
13. Z. Y. Wu, R. G. Hill, S. Yue, D. Nightingale, P. D. Lee et al. Melt-derived bioactive glass scaffolds produced by a gel-cast foaming technique, Acta Biomaterialia 7(4) 1807-1816 (2011).

14. Q. Fu, E. Saiz, A. P. Tomsia. Bioinspired strong and highly porous glass scaffolds, Advanced Functional Materials 21(6) 1058-1063 (2011).

15. R. Li, A. E. Clark, L. L. Hench. An investigation of bioactive glass powders by sol-gel processing, Journal of Applied Biomaterials 2(4) 231-239 (1991).

16. S. Lin, C. Ionescu, K. J. Pike, M. E. Smith, J. R. Jones. Nanostructure evolution and calcium distribution in sol-gel derived bioactive glass, Journal of Materials Chemistry 19(9) 1276-1282 (2009).

17. P. Saravanapavan, J. R. Jones, R. S. Pryce, L. L. Hench. Bioactivity of gelglass powders in the $\mathrm{CaO}-\mathrm{SiO} 2$ system: A comparison with ternary (CaO-P2O5$\mathrm{SiO} 2)$ and quaternary glasses (SiO2-CaO-P205-Na20), Journal of Biomedical Materials Research Part A 66A(1) 110-119 (2003).

18. J. Brinker, G. W. Scherer. Sol-gel science : the physics and chemistry of solgel processing. Boston: Academic Press; 1990.

19. P. Sepulveda, J. R. Jones, L. L. Hench. Characterization of melt-derived 45S5 and sol-gel-derived 58S bioactive glasses, Journal of Biomedical Materials Research 58(6) 734-740 (2001).

20. P. Saravanapavan, L. L. Hench. Mesoporous calcium silicate glasses. II. Textural characterisation, Journal of Non-Crystalline Solids 318(1-2) 14-26 (2003).

21. E. M. Valliant, C. A. Turdean-Ionescu, J. V. Hanna, M. E. Smith, J. R. Jones. Role of $\mathrm{pH}$ and temperature on silica network formation and calcium incorporation into sol-gel derived bioactive glasses, Journal of Materials Chemistry 22(4) 1613-1619 (2012).

22. P. Sepulveda, J. R. Jones, L. L. Hench. Bioactive sol-gel foams for tissue repair, Journal of Biomedical Materials Research 59(2) 340-348 (2002).

23. J. R. Jones, L. M. Ehrenfried, L. L. Hench. Optimising bioactive glass scaffolds for bone tissue engineering, Biomaterials 27 964-973 (2006).

24. J. R. Jones, G. Poologasundarampillai, R. C. Atwood, D. Bernard, P. D. Lee. Non-destructive quantitative 3D analysis for the optimisation of tissue scaffolds, Biomaterials 28 1404-1413 (2007).

25. J. R. Jones, L. L. Hench. Effect of surfactant concentration and composition on the structure and properties of sol-gel-derived bioactive glass foam scaffolds for tissue engineering, Journal of Materials Science 38(18) 3783-3790 (2003). 26. J. R. Jones, L. L. Hench. Factors affecting the structure and properties of bioactive foam scaffolds for tissue engineering, Journal of Biomedical Materials Research Part B-Applied Biomaterials 68B(1) 36-44 (2004).

27. J. R. Jones, S. Ahir, L. L. Hench. Large-scale production of 3D bioactive glass macroporous scaffolds for tissue engineering, Journal of Sol-Gel Science and Technology 29(3) 179-188 (2004).

28. V. FitzGerald, K. O. Drake, J. R. Jones, M. E. Smith, V. Honkimaki et al. In situ high-energy X-ray diffraction study of a bioactive calcium silicate foam immersed in simulated body fluid, Journal of Synchrotron Radiation $14492-499$ (2007).

29. V. FitzGerald, R. A. Martin, J. R. Jones, D. Qiu, K. M. Wetherall et al. Bioactive glass sol-gel foam scaffolds: Evolution of nanoporosity during processing and in situ monitoring of apatite layer formation using small- and 
wide-angle X-ray scattering, Journal of Biomedical Materials Research Part A 91A(1) 76-83 (2009).

30. ISO 23317 Implants for surgery-Hydroxyapatite-Part 1: Ceramic hydroxyapatite 2000 .

31. J. R. Jones, O. Tsigkou, E. E. Coates, M. M. Stevens, J. M. Polak et al. Extracellular matrix formation and mineralization of on a phosphate-free porous bioactive glass scaffold using primary human osteoblast (HOB) cells,

Biomaterials 28 1653-1663 (2007).

32. P. Valerio, M. M. Pereira, A. M. Goes, M. F. Leite. Effects of extracellular calcium concentration on the glutamate release by bioactive glass (BG60S) preincubated osteoblasts, Biomedical Materials 4(4) 7 (2009).

33. S. Midha, W. van den Bergh, T. B. Kim, P. D. Lee, J. R. Jones et al. Bioactive glass foam scaffolds are remodelled by osteoclasts and support the formation of mineralized matrix and vascular networks in vitro, Advanced Healthcare Materials 2(3) 490-499 (2013).

34. S. Midha, T. B. Kim, W. van den Bergh, P. D. Lee, J. R. Jones et al.

Preconditioned 70S30C bioactive glass foams promote osteogenesis in vivo, Acta Biomaterialia 9(11) 9169-9182 (2013).

35. S. Wang, M. M. Falk, A. Rashad, M. M. Saad, A. C. Marques et al. Evaluation of 3D nano-macro porous bioactive glass scaffold for hard tissue engineering, Journal of Materials Science-Materials in Medicine 22(5) 1195-1203 (2011).

36. R. M. Almeida, A. Gama, Y. Vueva. Bioactive sol-gel scaffolds with dual porosity for tissue engineering, Journal of Sol-Gel Science and Technology 57(3) 336-342 (2011).

37. A. C. Marques, R. M. Almeida, A. Thiema, S. Wang, M. M. Falk et al. Sol-gelderived glass scaffold with high pore interconnectivity and enhanced bioactivity, Journal of Materials Research 24(12) 3495-3502 (2009).

38. P. Valerio, M. H. R. Guimaraes, M. M. Pereira, M. F. Leite, A. M. Goes. Primary osteoblast cell response to sol-gel derived bioactive glass foams, Journal of Materials Science-Materials in Medicine 16(9) 851-856 (2005).

39. M. D. Coelho, M. M. Pereira. Sol-gel synthesis of bioactive glass scaffolds for tissue engineering: Effect of surfactant type and concentration, Journal of Biomedical Materials Research Part B-Applied Biomaterials 75B(2) 451-456 (2005).

40. L. J. Gibson, M. F. Ashby. Cellular Solids Structure and Properties. Oxford: Pergamon Press; 1988.

41. T. Kokubo, H. Kushitani, S. Sakka, T. Kitsugi, T. Yamamuro. Solution able to reproduce in vivo surface-structure in bioactive glass-ceramic A-W3, Journal of Biomedical Materials Research 24(6) 721-734 (1990).

42. A. L. B. Macon, T. B. Kim, E. M. Valliant, K. Goetschius, R. K. Brow et al. A unified in vitro evaluation for apatite-forming ability of bioactive glasses and their variants, Journal of Materials Science-Materials in Medicine 26(2) (2015). 43. J. R. Jones, T. F. Kemp, M. E. Smith. Effect of OH content on the bioactivity of sol-gel derived glass foam scaffolds, Key Engineering Materials 309-311 10311034 (2006).

44. T. Kokubo, H. Takadama. How useful is SBF in predicting in vivo bone bioactivity?, Biomaterials 27(15) 2907-2915 (2006).

45. M. Bohner, J. Lemaitre. Can bioactivity be tested in vitro with SBF solution?, Biomaterials 30(12) 2175-2179 (2009). 



\section{Figures}

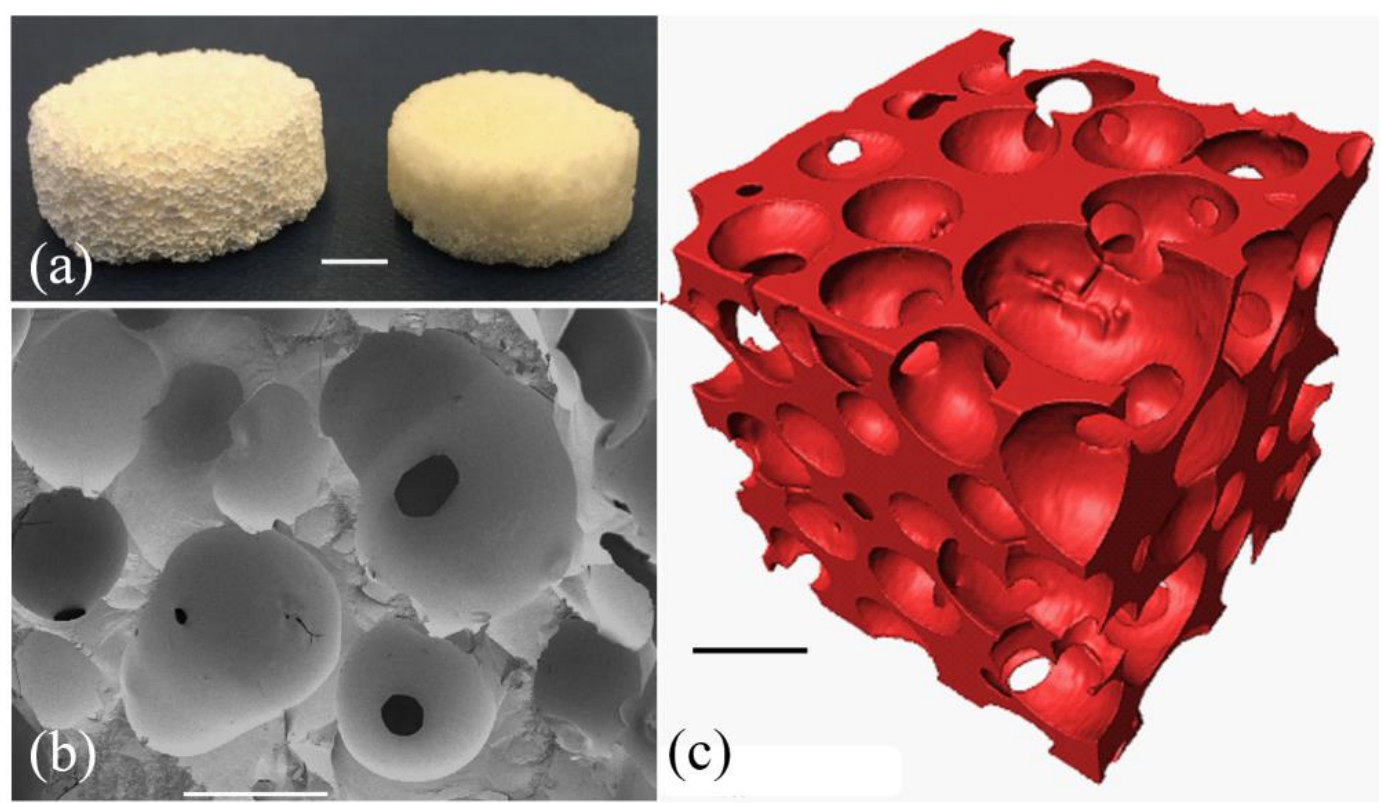

Figure 1. Bioactive glass sol-gel foam scaffolds (a) photographs after stabilisation at $600^{\circ} \mathrm{C}$ (left) and after sintering at $800^{\circ} \mathrm{C}$, scale bar $=5 \mathrm{~mm}$; (b) SEM image of a fracture surface, scale bar $=500 \mu \mathrm{m}$; (c) X-ray microtomography 3D image, scale bar $=500 \mu \mathrm{m}$. 

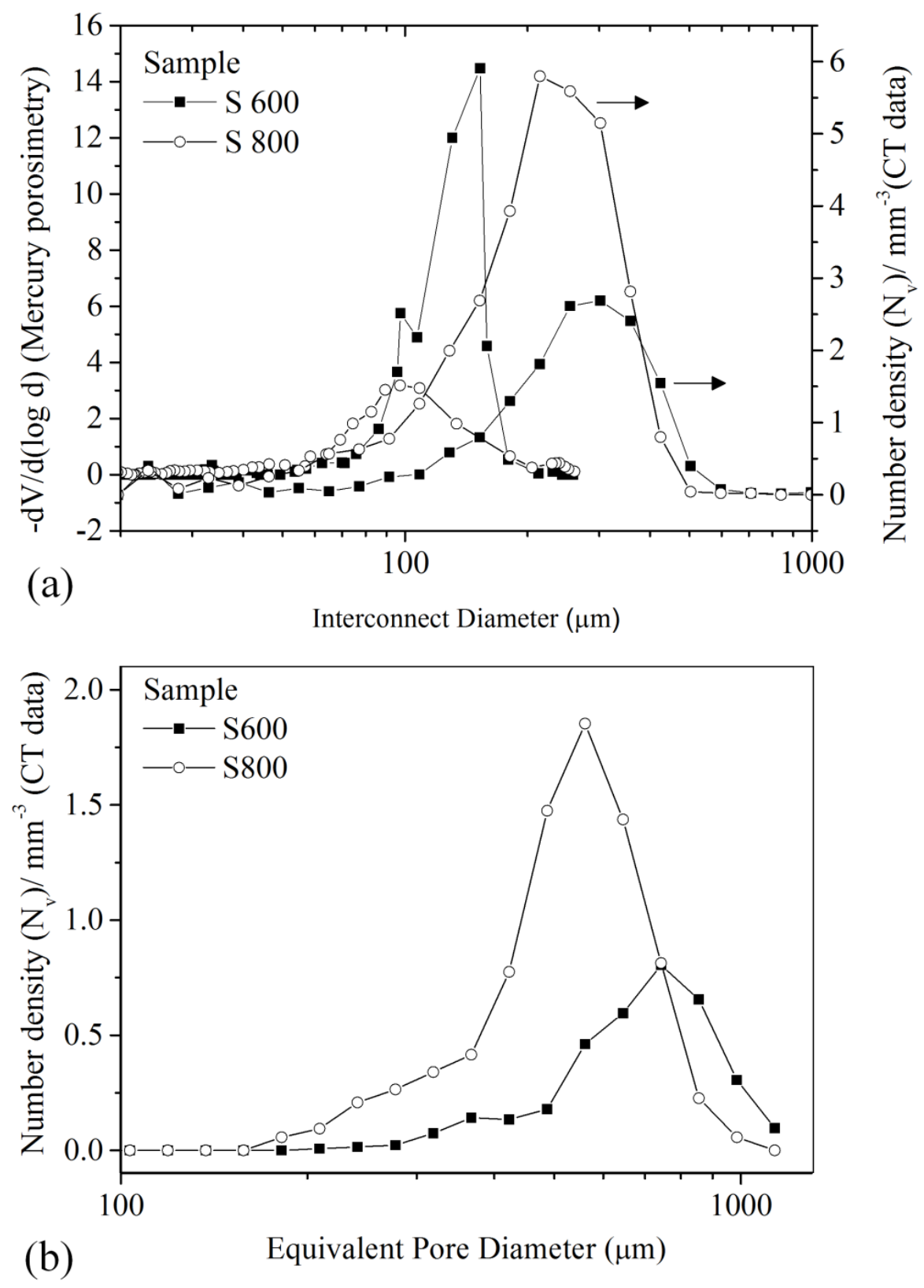

Figure 2. Pore size distributions for bioactive sol-gel foam scaffolds, stabilised at $600^{\circ} \mathrm{C}$ with initial $\rho$ (foam density) of $0.22 \mathrm{~g} \mathrm{~cm}^{-3}$ and porosity of $92 \%$, then sintered to $800^{\circ} \mathrm{C}$ to give a $\rho_{\mathrm{f}}$ (foam density) of $0.41 \mathrm{~g} \mathrm{~cm}^{-3}$ and porosity of $85 \%$ :

(a) Interconnect size distributions from mercury porosimetry and X-ray microtomography (data replotted from Jones et al. ${ }^{24}$ ); (b) Pore size distributions from X-ray microtomography (data replotted from Jones et al. ${ }^{24}$ ). 


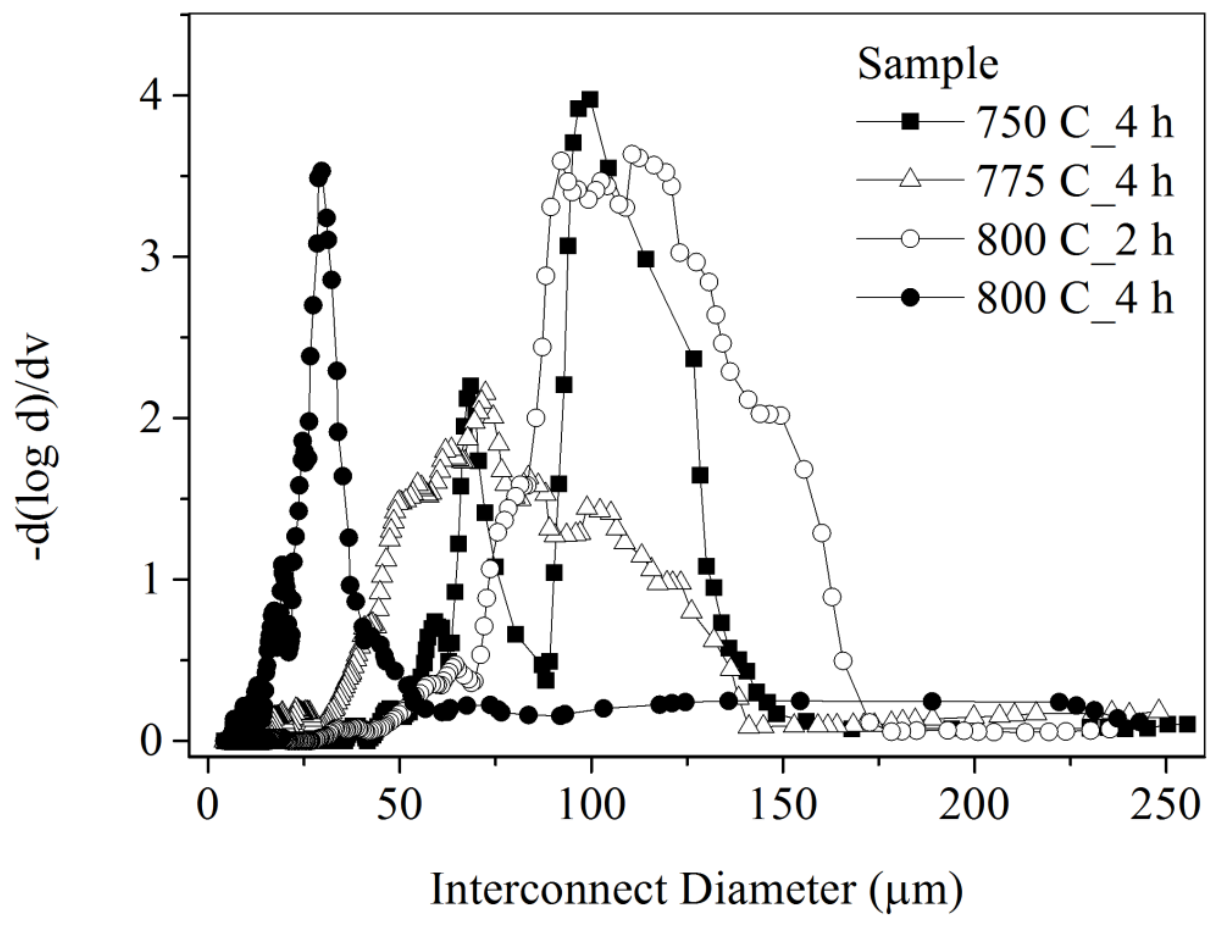

Figure 3. Interconnect size distributions for bioactive sol-gel foam scaffolds, stabilised at $600{ }^{\circ} \mathrm{C}$ with initial $\rho_{\mathrm{f}}$ (foam density) of $0.21 \mathrm{~g} \mathrm{~cm}^{-3}$ and porosity of $93 \%$, then sintered to different temperatures for $2 \mathrm{~h}$ or $4 \mathrm{~h}$. 

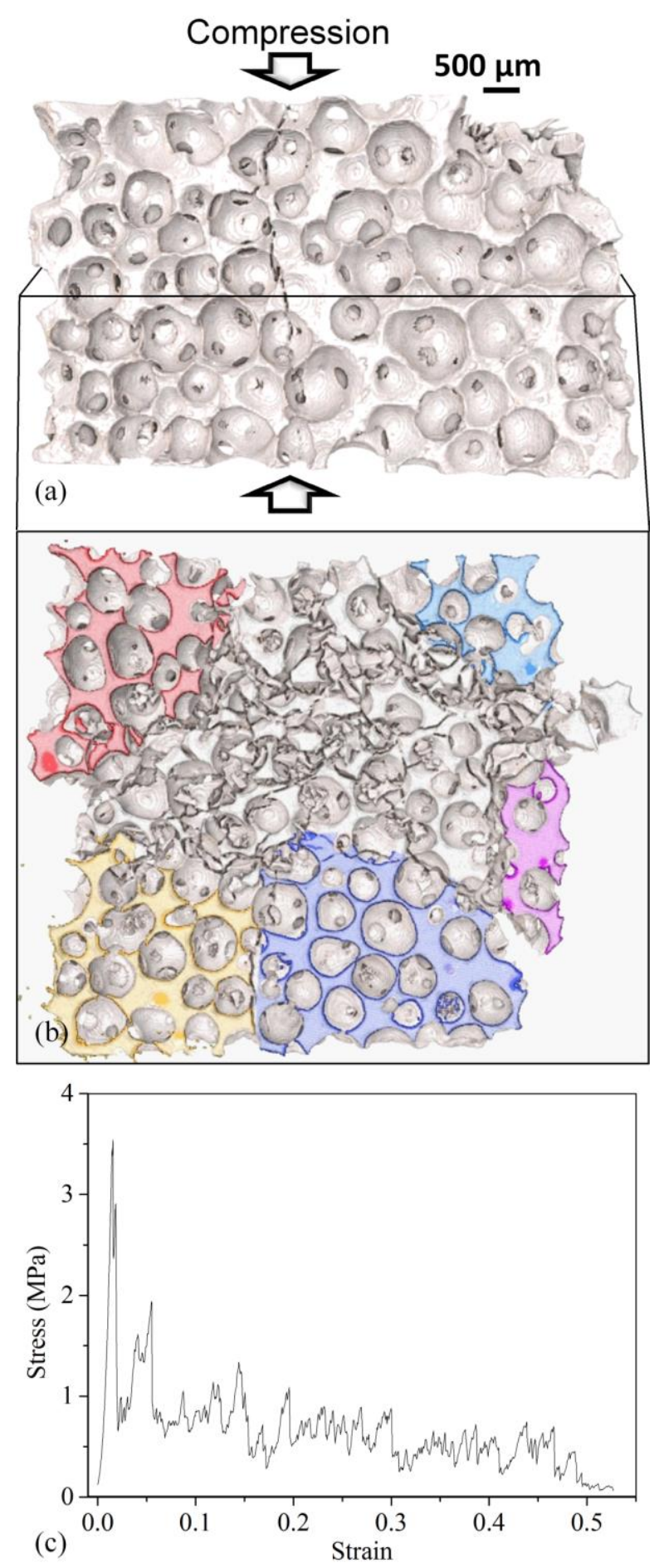

Figure 4. (a) X-ray microtomography $(\mu \mathrm{CT})$ image of a crack in a bioactive glass foam scaffold immediately after fracture; (b) A $\mu \mathrm{CT}$ image of a cross-section through (a) with several individual fractured pieces of the foam coloured differently; (c) Representative compression stress-strain graph for a sol-gel foam scaffold. This example was a scaffold heated to $750^{\circ} \mathrm{C}$ for $4 \mathrm{~h}$. 


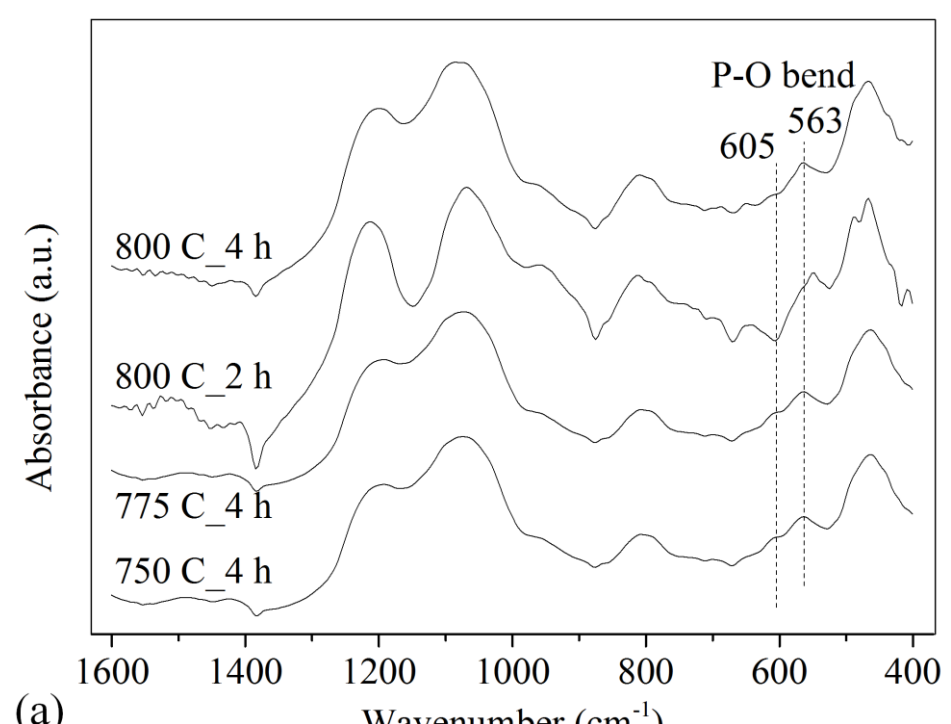

(a) Wavenumber $\left(\mathrm{cm}^{-1}\right)$

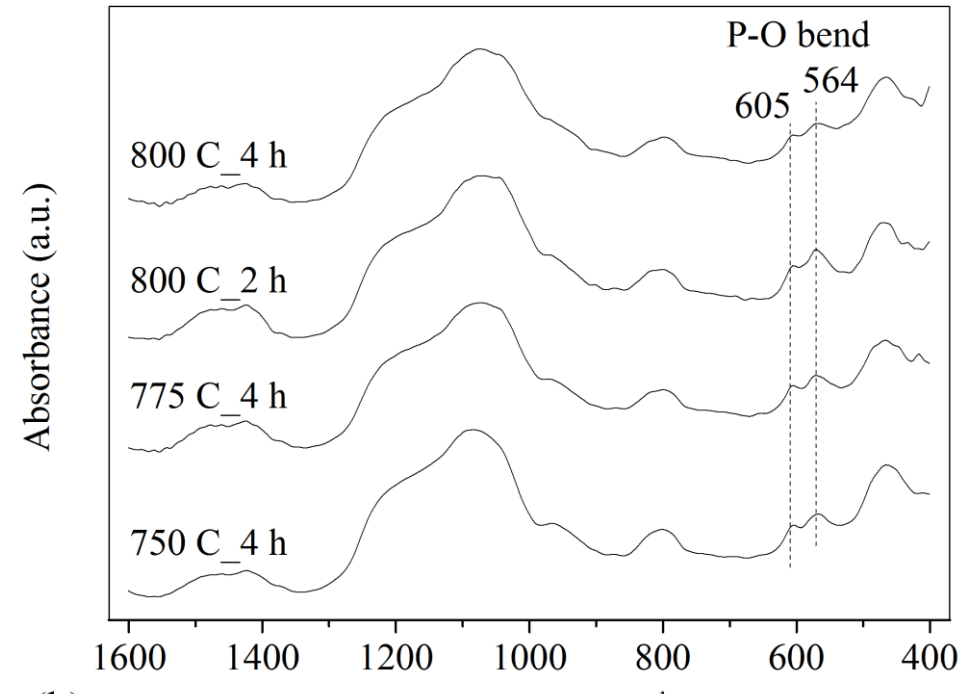

(b) Wavenumber $\left(\mathrm{cm}^{-1}\right)$

Figure 5. FTIR spectra from sol-gel foam 70S30C scaffolds, for different sintering temperatures and times, following immersion in SBF for: (a) $24 \mathrm{~h}$; (b) 1 week. 

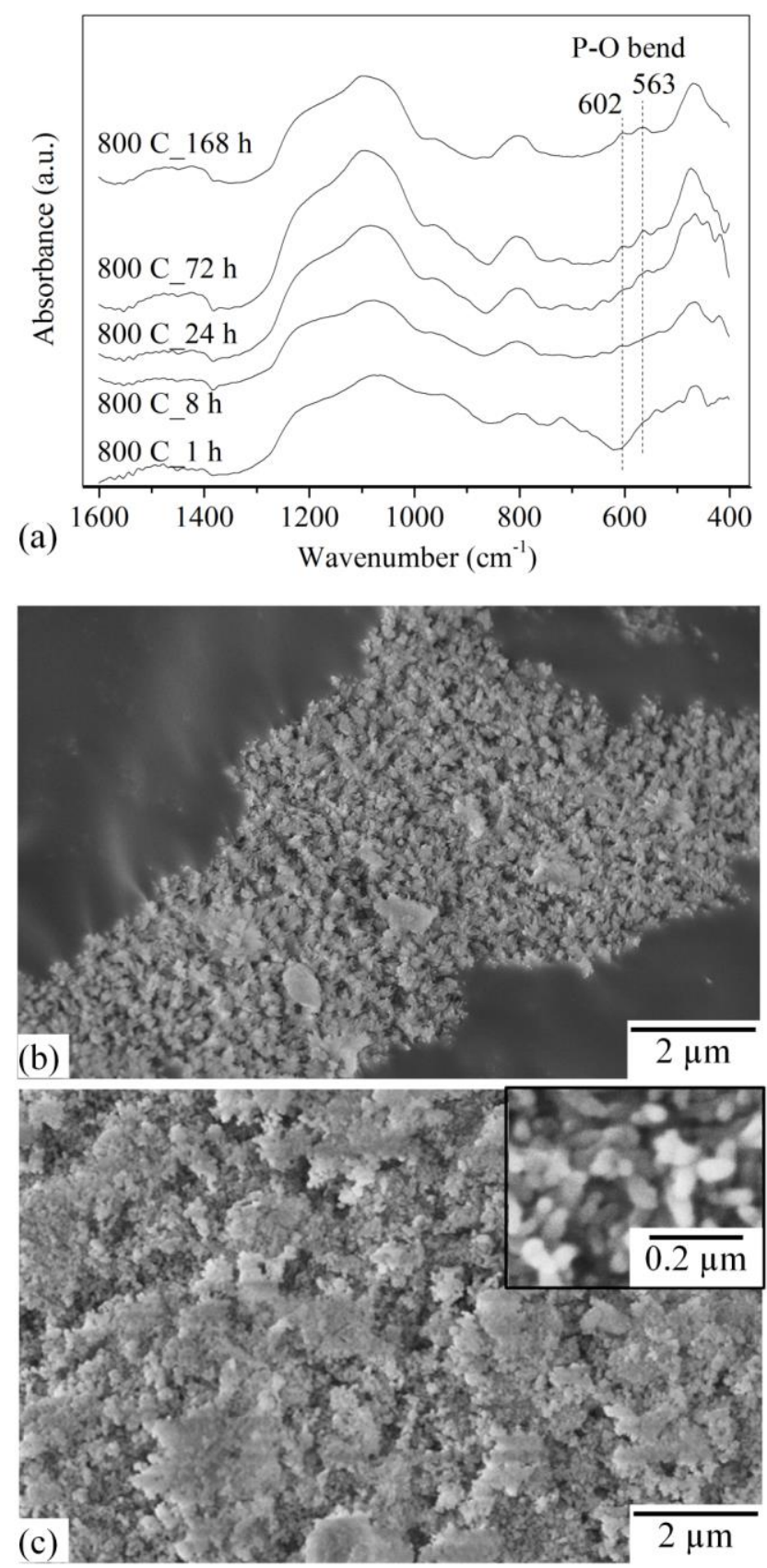

Figure 6. (a) FTIR spectra from sol-gel foam 70S30C scaffolds, sintered at $800^{\circ} \mathrm{C}$ for 2 hours, following immersion in SBF for 1, 8, 24, 72 and $168 \mathrm{~h}$; SEM images of the sol-gel foam $70 \mathrm{~S} 30 \mathrm{C}$ scaffolds sintered at $800^{\circ} \mathrm{C}$ for $2 \mathrm{~h}$ after soaking in SBF for (b) 3 days and (c) 7 days. Inset of (c) shows high magnification SEM images of the needle like HCA crystals formed on the surface of the scaffolds. 
Table 1. Characterisation summary for $70 \mathrm{S30C}$ bioactive glass sol-gel foams: $T_{\mathrm{s}}$ $=$ sintering temperature, $t_{\mathrm{s}}=$ sintering hold time $\rho_{\mathrm{f}}=$ foam density, $\mathrm{D}=$ interconnected pore diameter, $\sigma_{\max }=$ maximum compressive strength; $\mathbf{t}_{\mathrm{HCA}}=$ time of HCA layer formation (from FTIR).

\begin{tabular}{|c|c|c|c|c|c|}
\hline $\begin{array}{c}\mathrm{T}_{\mathrm{s}} \\
{\left[{ }^{\circ} \mathrm{C}\right]}\end{array}$ & $\begin{array}{c}\mathrm{t}_{\mathrm{s}} \\
{[\mathrm{h}]}\end{array}$ & $\begin{array}{c}\rho_{\mathrm{f}} \\
{\left[\mathrm{g} \mathrm{cm}^{-3}\right]}\end{array}$ & $\begin{array}{c}\text { Modal D } \\
{[\mu \mathrm{m}]}\end{array}$ & $\begin{array}{c}\sigma_{\max } \\
{[\mathrm{MPa}]}\end{array}$ & $\begin{array}{c}\mathrm{t}_{\mathrm{HCA}} \\
{[\mathrm{h}]}\end{array}$ \\
\hline 750 & 4 & 0.22 & 104 & $2.3 \pm 0.9$ & 24 \\
\hline 775 & 4 & 0.42 & 71 & $4.48 \pm 1.0$ & 168 \\
\hline 800 & 2 & 0.45 & 116 & $4.58 \pm 0.9$ & 168 \\
\hline 800 & 4 & 0.48 & 31 & $4.56 \pm 1.0$ & 168 \\
\hline
\end{tabular}

Table 2. Compressive strength of 70S30C bioactive glass sol-gel foams sintered at $800{ }^{\circ} \mathrm{C}$ for $2 \mathrm{~h}$, following immersion in SBF: $\rho_{\mathrm{f}}=$ foam density; $\% \mathrm{P}=$ percentage porosity $; \sigma_{\max }=$ maximum compressive strength.

\begin{tabular}{|c|c|c|c|}
\hline $\begin{array}{c}\text { Time in SBF } \\
{[\mathrm{h}]}\end{array}$ & $\begin{array}{c}\rho_{\mathrm{f}} \\
{\left[\mathrm{g} \mathrm{cm}^{-3}\right]}\end{array}$ & $\% \mathrm{P}$ & $\begin{array}{c}\sigma_{\max } \\
{[\mathrm{MPa}]}\end{array}$ \\
\hline 0 & 0.60 & 78 & $6.0 \pm 0.8$ \\
\hline 2 & 0.58 & 79 & $5.2 \pm 0.6$ \\
\hline 24 & 0.57 & 79 & $4.4 \pm 0.4$ \\
\hline 72 & 0.56 & 80 & $5.0 \pm 0.5$ \\
\hline 168 & 0.38 & 86 & $2.1 \pm 0.1$ \\
\hline
\end{tabular}

